\title{
PERKEMBANGAN SIKAP SOSIAL ANAK MELALUI PROSES APRESIASI TERHADAP TRADISI SAMBATAN DI DESA DERMOLO, JEPARA by Wahyu Candra
}

Submission date: 28-Mar-2020 07:54PM (UTC+0700)

Submission ID: 1283912875

File name: ARTIKEL_JURNAL_SAMBATAN.pdf (434.54K)

Word count: 3465

Character count: 22861 


\title{
DIDAKTIKA
}

Jurnal Pendidikan Sekolah Dasar

Volume X, Nomor X, X-X, XXXX

Journal homepage: https://journal.uny.ac.id/index.php/didaktika

THE DEVELOPMENT OF CHILDREN'S SOCIAL ATTITUDES THROUGH APPRECIATION PROCESS OF

THE SAMBATAN TRADITION IN DERMOLO VILLAGE, JEPARA

Wahyu Candra ${ }^{1,}$, Nur Fajrie'2, Deka Setiawan ${ }^{3}$

UUniversitas Muria Kudus, Indonesia

\section{Abstract}

This research aims to describe the Sambatan Tradition in DermoloVillage, the values of character education in it and its influence on children's social behavior through an appreciation process. This research uses descriptive method with a phenomenological approach. The object of this research is the Sambatan Tradition in Dermolo Village, while the subject is the Dermolo Village community. The targets of this research are the Sambatan Traders, Dermolo Village community leaders, SDN 03 Dermolo principals, teachers and students. Data obtained through in-depth interview, observation, documentation and recording. There are two sources of data in this research, namely the Dermolo Village community who are directly involved with the Sambatan Tradition and education practitioners at SDN 03 Dermolo including students. Validity test uses source triangulation techniques. Data analysis techniques using data reduction, data presentation and conclusion or verification. The Sambatan Tradition with its character education value has a great influence on the lives of the people of Dermolo Village and encourages the appreciation of children. Sustainability of the Sambatan Tradition with values of tolerance, social care and environmental care implied in it has an influence on children's development, especially social attitudes in daily life.

Keywords: Sambatan Tradition, appreciation, character, social attitudes of children

\section{PERKEMBANGAN SIKAP SOSIAL ANAK MELALUI PROSES APRESIASI TERHADAP TRADISI SAMBATAN DI DESA DERMOLO, JEPARA}

\begin{abstract}
Abstrak
Penelitian ini bertujuan untuk mendeskripsikan Tradisi Sambatan yang ada di Desa Dermolo, nilai-nilai pendidikan karakter yang ada didalamnya dan pengaruhnya terhadap sikap sosial anak-anak melalui proses apresiasi. Penelitian ini menggunakan metode kualitatif deskriptif dengan pendekatan fenomenologis. Objek penelitian ini adalah Tradisi Sambatan di Desa Dermolo, sedangkan subjeknya adalah masyarakat Desa Dermolo. Sasaran penelitian ini adalah pelaku Tradisi Sambatan, tokoh masyarakat Desa Dermolo, kepala sekolah SDN 03 Dermolo, wali kelas dan para iswa. Data didapatkan melalui wawancara mendalam, observasi, dokumentasi dan pencatatan. Terdapat 2 sumber data dalam penelitian ini, yaitu masyarakat Desa Dermolo yang terlibat secara langsung dengan Tradisi Sambatan dan praktisi pendidikan di SDN 03 Dermolo termasuk para siswa. Uji validitas menggunakan teknik triangulasi sumber. Teknik analisis data menggunakan reduksi data, penyajian data dan kesimpulan atau verifikasi. Tradisi Sambatan dengan nilai pendidikan karakternya membawa pengaruh yang besar bagi kehidupan masyarakat Desa Dermolo dan mendorong adanya apresiasi dari anak-anak. Keberlangsungan Tradisi Sambatan dengan nilai-nilai toleransi, peduli sosial dan peduli lingkungan yang tersirat didalamnya membawa pengaruh terhadap perkembangan anak terutama sikap sosial dalam kehidupan sehari-hari.
\end{abstract}

Kata kunci: Tradisi Sambatan, apresiasi, karakter, sikap sosial anak.

Corresponding Author: Affiliation Address: $x x x x$

E-mail: xxxx@xxxx.ac.id 


\section{PENDAHULUAN}

Kebudayaan merupakan salah satu topik yang sangat menarik untuk dibahas oleh semua orang karena memiliki kompleksifitas yang tinggi dan memiliki pengaruh yang luas dalam kahidupan manusia. (Tylor, 1871: 1) menegaskan kebudayaan adalah suatu kompleks yang meliputi ilmu pengetahuan, kepercayaan, kesenian, akhlak, hukum, adat dan banyak kemempuan-kemampuan dan kebiasaan-kebiasaan lain yang diperoleh manusia sebagai anggota masyarakat. Kebudayaan khususnya tradisi terbentuk dari pikiran dan perbuatan manusia yang telah ada sejak zaman dahulu, hal tersebut diperkuat oleh pernyataan (Muti'ah, 2009: 15) yang mengatakan bahwa tradisi secara umum dipahami sebagai pengetahuan, doktrin, kebiasaan, praktik dan lain-lain yang diwariskan turun-temurun termasuk cara penyampaian pengetahuan.

Indonesia sebagai bangsa yang majemuk dengan keanekaragamannya memiliki berbagai bentuk kebudayaan yang unik. Peran sosial dibangun dari interaksi masyarakat terhadap pendukungnya, ritualitas budaya hingga saat ini masih terjaga dan dilestarikan. Salah satu hasil budaya yang hingga saat ini masih dilaksanakan terutama masyarakat didaerah jawa adalah Tradisi Sambatan khususnya yang ada di Desa Dermolo, Kecamatan Kembang, Kabupaten Jepara. Hal tersebut diperkuat oleh (Koentjaraningrat, 1985: 58) bahwa istilah sambatan berasal dari Bahasa Jawa, yaitu kata "sambat" yang artinya "meminta bantuan". Tradisi Sambatan yang telah ada sejak jaman dahulu dan diwariskan dari generasi ke generasi telah menjadi tradisi yang memiliki pengaruh besar bagi masyarakat Desa Dermolo sebagai berwujudan nilai-nilai luhur yang diciptakan oleh masyarakat sejak jaman dahulu.

Nilai-nilai luhur Tradisi Sambatan di Desa Dermolo kental kaitannya pendidikan sosial kemasyarakatan yang mengalami perkembangan menjadi nilai-nilai pendidikan karakter jika dihubungkan dengan dunia pendidikan formal. Tradisi Sambatan yang telah mendarah daging dalam kehidupan masyarakat Desa Dermolo telah menjadi warisan budaya masyarakat yang harus dilestarikan karena memiliki pengaruh besar bagi masayarakat sekaligus sebagai wujud apresiasi terhadap makna Tradisi Sambatan itu sendiri.
Apresiasi yang menjadi wujud dari respon sosial masyarakat dapat bersumber dari berbagai elemen, seperti tokoh masyarakat, pemerintah desa, warga desa bahkan anak-anak desa sebagai pewaris dan penerus Tradisi Sambatan. Akan tetapi perlu dikaji lebih jauh lagi bagaimana bentuk apresiasi anak terhadap Tradisi Sambatan yang ada di Desa Dermolo. Berawal dari respon sosial itu lah peneliti merasa perlu untuk melakukan penelitian terhadap Representasi Sosial dalam Pendidikan Karakter: Responitas Apresiasi Anak-Anak terhadap Tradisi Sambatan di Desa Dermolo.

\section{METODE PENELITIAN}

Metode yang penelitian yang digunakan adalah metode kualitatif deskriptif. Pendekatan yang digunakan oleh peneliti adalah pendekatan fenomenologis dengan pertimbangan bahwa penelitian ini berupaya mendeskripsikan fenomena Tradisi Sambatan dengan nilai-nilai pendidikan karakter didalamnya yang telah mendorong adanya proses apresiasi oleh anak-anak dan pengaruhnya terhadap perkembangan sikap sosial anak Desa Dermolo dalam kehidupan sehari-hari.

Lokus penelitian di Desa Dermolo, Kecamatan Kembang, Kabupaten Jepara yang terdiri dari 8 dukuh, yaitu: Dukuh Wates, Dukuh Dombang, Dukuh Ngetuk, Dukuh Gundi, Dukuh Punden, Dukuh Ngemplik, Dukuh Kecipir, Dukuh Sentul dan si SDN 03 Dermolo. Pemilihan lokasi ditentukan secara purposive (sengaja). Penelitian dilakukan dalam periode tertentu selama 5 (lima) bulan dari Bulan November 2019 sampai Bulan Maret 2020.

Teknik pengumpulan data dilakukan pada natural setting (kondisi alamiah) dengan metode wawancara mendalam, observasi, dokumentasi dan pencatatan. Sumber data terbagi menjadi dua, yaitu dari lingkungan masyarakat (Desa Dermolo) dan lingkungan pendidikan formal (SDN 03 Dermolo). Informan dari lingkungan masyarakat adalah tokoh masyarakat, perangkat desa, ketua RW, ketua RT dan masyarakat yang terlibat secara langsung dengan Tradisi Sambatan tersebut. Sedangkan informan dari lingkungan pendidikan adalah kepala sekolah, wali kelas dan siswa-siswi SDN 03 Dermolo.

Hasil dari data tersebut dicari dengan persamaanya sehingga peneliti dapat melakukan analisis data yang dijadikan sebagai hasil dari penelitian yang akan disajikan dalam 
bentuk deskripsi sehingga peneliti akan memperoleh data yang objektif. (Sugiyono 2016) analisis data kualitatif dilakukan pada saat pengumpulan data berlangsung dan setelah pengumpulan data pada periode tertentu.

Uji validitas menggunakan teknik triangulasi sebagai teknik pemeriksaan data. (Moleong 2010: 331), Hal tersebut dapat dicapai dengan cara sebagai berikut: (1) Membandingkan data hasil pengamatan dengan hasil wawancara; (2) Membandingkan keadaan dan perspektif seseorang dengan berbagai pendapat dan pandangan orang lain, selain guru dan siswa; (3) Membandingkan hasil wawancara dengan isi suatu dokumen yang berkaitan.

Teknik analisis data yang digunakan dalam penelitian ini adalah model analisis intraktif (Miles \& Huberman 1992: 20) dengan melakukan data reduction (reduksi data), display (penyajian data), conclusion and verification (menarik kesimpulan dan verifikasi)..

\section{HASIL DAN PEMBAHASAN}

Masyarakat Desa Dermolo yang hingga saat ini masih melestarikan Tradisi Sambatan sekaligus berupaya menanamkan nilai-nilai luhur yang ada didalamnya kepada generasi penerus merupakan proses pendidikan yang nyata dalam kehidupan sehari-hari. (Listyarti, 2012), pendidikan merupakan proses yang terjadi secara terus menerus dari penyesuaian yang lebih tinggi bagi manusia yang berkembang secara fisik dan mental, yang bebas dan sadar kepada Tuhan, seperti termanifestasi di alam sekitar, intelektual, emosional dan kemanusiaan dari manusia. Dari proses pendidikan yang tanpa disadari tersebutlah mucul respon-respon sosial dari berbagai lapisan masyarakat termasuk anak-anak di Desa Dermolo yang selama ini akrab dengan Tradisi Sambatan di lingkungan tempat tinggal mereka.

Berdasarkan hasil penelitian yang telah dilakukan, terdapat beberapa hal yang menjadi fokus bagi penelitian ini, antara lain:

\section{Bentuk-Bentuk Tradisi Sambatan yang ada di Desa Dermolo}

A. Kerja bakti

Kegiatan kerja bakti di Desa Dermolo dilakukan dalam situasi dan kondisi tertentu seperti perbaikan jalan dan pembersihan lingkungan desa. Selain bertujuan memperbaiki atau membersihkan, diwaktu tertentu kegiatan kerja bakti di Desa Dermolo dilakukan dengan berbagai tujuan untuk kepentingan bersama.

B. Ngeronda (jaga malam)

Kegiatan Ngeronda atau jaga malam dilakukan oleh bapak-bapak atau para pemuda desa dan dilaksanakan secara rutin setiap malam sesuai jadwal yang sudah disepakati bersama-sama.

C. Sambatan Gawe Omah (membangun atau memperbaiki rumah)

Tradisi Sambatan Gawe Omah merupakan kegiatan yang paling terkenal di Desa Dermolo, kegiatan membangun dan memperbaiki rumah biasanya dilakukan oleh orang dewasa dengan pembagian tugas mulai dari tahap awal hingga tahap akhir. Para laki-laki bertugas melakukan pekerjaan inti untuk membangun atau memperbaiki sedangkan para perempuan bertugas didapur untuk mempersiapkan konsumsi dan pekerjaan ringan lainnya.

D. Sambatan Mlandang (bantuan dalam kegiatan hajatan)

Hajatan yang dimaksud mencakup berbagai kegiatan, baik berskala kecil hingga berskala besar seperti khitanan, pernikahan, selamatan dan lain-lain yang pelaksanaannya membutuhkan waktu bervariasi sesuai dengan kebutuhan, sambatan mlandang dalam kegiatan hajatan ini membutuhkan banyak tenaga dari orang dewasa, pemuda hingga anakanak dengan peran yang berbeda pula.

E. Sambatan Ndaut, Tandur, Bedhok, Panen dan lain-lain (kegiatan dibidang pertanian)

Desa Dermolo sebagai salah satu wilayah yang memiliki lahan pertanian cukup luas, secara otomatis juga memiliki banyak petani yang mengolah lahan pertanian tersebut. Jenis tanaman yang ditanam pun sangat beragam bergantung pada musim dan kebutuhan, dalam kegiatan bercocok tanam itulah para petani membutuhkan banyak bantuan 


\section{4| First Author, Second Author, \& Third Author (Last Name)}

agar pekerjaan dapat selesai dengan baik terutama tanaman yang diolah dengan jumlah besar seperti padi, kacang tanah dan jagung.

F. Sambatan saat pemakaman

Bentuk samabatn ini merupakan kegiatan yang ada di berbagai tempat terutama didaerah pedesaan. Apabila ada salah seorang warga yang meninggal dunia, maka para keluarga dan tetangga terdekat bergotong royong membantu mempersiapkan semua keperluan yang dibutuhkan dalam proses pemakaman dari awal hingga akhir.

\section{Pendidikan Karakter dalam Budaya Tradisi Sambatan di Desa Dermolo}

(Kus, 2018: 44), Dewasa ini urgensi pendidikan karakter sebagai bagian integraldari upaya pengembangan siswa secara holostik mulai mendapat perhatian serius. Hal tersebut didasari pemikiran bahwa pendidikan selama ini cenderung memberi porsi yang berlebih kepada peneneman aspek-aspek kompetensi yang bersifat hard skill dan kurang memberi porsi yang layak terhadap penanman soft skill atau karakter. (Sulhan, 2018: 170) menyimpulkan bahwa tujuan dari pendidikan karakter berbasis budaya adalah penanaman nilai-nilai khusus pada diri siswa sesuai dengan karakter bangsa Indonesia yaitu Pancasila dan nilai luhur budaya bangsa.

Tradisi Sambatan yang ada di Desa Dermolo menjadi objek pendidikan karakter yang dipelajari oleh anak-anak Desa Dermolo sebagai generasi penerus yang akan melestarikan Tradisi Sambatan dengan berbagai dampak positif yang telah dirasakanoleh masyarakat dalam kehidupan sehari-hari. Pendidikan karakter yang dominan dalam Tradisi Sambatan yang dilaksanakan oleh masyarakat Desa Dermolo adalah nilai-nilai gotong royong, toleransi, peduli sosial, peduli lingkungan. Hal tersebut diperkuat oleh penelitian yang dilakukan oleh (Nur dan Darmawan, 2016: 73) yang menyatakan bahwa Tradisi Sambatan manjadi suatu sistem norma dan pedoman masyarakat dalam gotong royong dan tolong menolong.

Pendidikan karekter yang terdapat dalam Tradisi Sambatan memang tidak terlihat keberadaannya, namun dampaknya dapat dirasakan secara luas oleh masyarakat Desa Dermolo sebagai pelaku Tradisi Sambatan tersebut dan telah memberikan perubahan besar, baik yang berupa fisik maupun non-fisik. Yang dimaksud sebagai perubahan fisik adalah berupa pembangunan yang dapat dilihat atau kasat mata, sedangkan pembangunan non-fisik adalah berupa suatu sistem norma atau pedoman hidup masyarakat untuk saling peduli, saling menghargai, mengutamakan kepentingan bersama, tolong menolong dan gotong royong sebagai perwujudan Tradisi Sambatan yang selama ini dilaksanakan.

Nilai-nilai pendidikan karakter yang ada pada Tradisi Sambatan tercipta secara alami oleh interaksi masyarakat Desa Dermolo dalam melaksanakan Tradisi Sambatan tersebut, Tradisi Sambatan yang merupakan kearifan lokal Desa Dermolo memiliki dampak yang besar bagi kehidupan masyarakat dari waktu kewaktu. Nilai-nilai luhur seperti gotong royong, toleransi, peduli sosial dan peduli lingkungan menjadi hal yang menonjol dalam kehidupan masyarakat Desa Dermolo, hal tersebut berkaitan erat dengan Tradisi Sambatan karena nilai-nilai tersebut terbentuk dari pelaksanaan Tradisi Sambatan oleh masyarakat Desa Dermolo yang telah diwariskan oleh para leluhur kepada generasi penerus.

\section{Apresiasi Anak-Anak Desa Dermolo terhadap Tradisi Sambatan}

Berapresiasi berarti menghargai dan melibatkan dua pihak, yaitu pihak yang dihargai dan pihak yang memberi penghargaan. Sebuah subjek dapat dikatakan melakukan apresiasi apabila telah melakukan proses pengamatan, penilaian dan pemberian respon terhadap suatu objek. (Jazuli, 2008: 16), melalui pengalaman estetis, seseorang (siswa) diharapkan dapat menginternalisasi (meresapi dan mengakarkan) nilai-nilai estetik yang berfungsi untuk melatih kepekaan rasa, kecerdasan intelektual dan mengembangkan imajinasinya. Oleh karena itu dapat diartikan bahwa aspresiasi merupakan respon alami dari subjek terhadap objek tertentu, dalam hal ini adalah anak-anak Desa Dermolo yang bersekolahdi SDN 03 Dermolo sebagai subjek yang melakukan apresiasi dan Tradisi Sambatan sebagai objek yang diapresiasi. 
Secara umum, Tradisi Sambatan melibatkan peran orang-orang dewasa dalam pelaksanaannya. Hal tersebut dikarenakan mayoritas kegiatan sambatan yang membutuhkan banyak tenaga dari orang dewasa. Meskipun demikian, keberadaan anakanak Desa Dermolo memiliki peranan tersendiri dalam Tradisi Sambatan, apresiasi yang diberikan anak-anak terhadap Tradisi Sambatan sangat penting untuk keberlangsungan Tradisi Sambatan tersebut, terlebih mereka adalah generasi yang akan meneruskan Tradisi Sambatan dimasa yang akan datang. (Desmond, 2011: 40), sebuah karya ciptaan manusia mendapat predikat sebagai karya seni jika dengan sengaja dibuat untuk dinikmati atau diapresiasi oleh masyarakat.

Apresiasi yang diberikan oleh anak-anak Desa Dermolo terhadap Tradisi Sambatan sangatlah beragam, bergantung pada bentukbentuk kegiatan sambatan yang dilaksanakan. Ada yang terlibat secara langsung dalam pelaksanaan Tradisi Sambatan dan ada juga yang tidak terlibat dalam pelaksanaan Tradisi Sambatan. Dapat dikatakan tidak terlibat karena anak-anak hanya sekadar melihat atau menyaksikan pelaksanaan Tradisi Sambatan, contohnya pada bentuk Tradisi Sambatan berupa pemakaman dan ngeronda (jaga malam) karena tidak memerlukan bantuan anak-anak dalam kegiatan tersebut. Akan tetapi sudah dapat dikatakan memberikan apresiasi karena ada proses pengamatan dan penilaian. Sedangkan dalam bentuk Tradisi Sambatan yang lain seperti kerja bakti bersih desa, gawe omah, mlandang, tandur, ndaut, bedhok dan panen (bidang pertanian), anak-anak Desa Dermolo terlibat secara langsung didalamnya dan dapat dikatakan melakukan apresiasi karena melakukan proses pengamatan, penilaian dan respon atau berperan dalam setiap kegiatan tersebut. Meskipun perannya sangat minim karena didominasi oleh orang dewasa, akan tetapi hal tersebut sangat penting bagi keberlangsungan Tradisi Sambatan yang ada di Desa Dermolo karena mendapatkan apresiasi dari generasi penerus.

Didalam berbagai kegiatan, anak-anak Desa Dermolo yang telah melakukan proses apresiasi mampu menyerap dan mengaplikasikan nilai-nilai pendidikan karakter yang ada dalam Tradisi Sambatan dalam kehidupan sehari-hari. Tingkat penanaman nilai-nilai luhur Tradisi Sambatan dapat diukur dari intensitas proses apresiasi terhadap Tradisi Sambatan baik berupa pengamatan, penilaian hingga pemberian respon atau tindakan. Anak yang sering melakukan proses apresiasi sejalan dengan nilai-nilai karakter yang ada dalam Tradisi Sambatan, begitu pun sebaliknya karena karakter anak dapat terbentuk dari kegiatan mereka sehari-harai, apa yang mereka lihat, apa yang mereka dengar, apa yang mereka rasakan dan apa yang mereka lakukan pasti akan berdampak pada pembentukan sikap dan perilaku mereka terhadap lingkungan atau orang sekitar

\section{Nilai-Nilai Pendidikan Karakter dalam Sikap Sosial Anak-Anak Desa Dermolo terhadap Tradisi Sambatan}

Nilai mengandung makna sifat atau kualitas dari segala sesuatu yang dipandang berharga atau bermanfaat dan oleh karena itu orang selalu mencarinya, (Rondhi, 2002: 11). Sedangkan karekter menurut (Gunarto, 2004: 22) merupakan nilai-nilai perilaku manusia yang berhubungan dengan Tuhan Yang Maha Esa, diri sendiri, sesama manusia, lingkungan dan kebangsaan yang terwujud dalam pikiran, sikap, perasaan, perkataan dan perbuatan berdasarkan norma-norma agama, budaya dan nilai kebangsaan yang diaktualisasikan dalam kehidupan sehari-hari menjadi suatu pembiasaan yang melekat. Nilai-nilai pendidikan karakter dapat terbentuk secara alamiah tanpa adanya tekanan dan paksaan kepada siapapun dari pihak manapun. Selain itu nilai-nilai pendidikan karakter dapat mempengaruhi berbagai hal termasuk sikap sosial.

Kemendiknas 2011 mengidentifikasi 18 nilai karakter sebagai berikut:

Tabel 1.18 Nilai-nilai pendidikan karakter

\begin{tabular}{|c|l|l|}
\hline No & \multicolumn{1}{|c|}{$\begin{array}{c}\text { Nilai } \\
\text { Karakter }\end{array}$} & \multicolumn{1}{|c|}{ Deskripsi } \\
\hline 1. & Religius & $\begin{array}{l}\text { Melaksanakan ajaran } \\
\text { agama }\end{array}$ \\
\hline 2. & Jujur & Dapat dipercaya \\
\hline 3. & Toleransi & $\begin{array}{l}\text { Menghargai segala } \\
\text { bentuk perbedaan }\end{array}$ \\
\hline 4. & Disiplin & Taat aturan \\
\hline 5. & Kerja Keras & Pantang menyerah \\
\hline 6. & Kreatif & Mengahasilkan cara \\
\hline
\end{tabular}




\section{First Author, Second Author, \& Third Author (Last Name)}

\begin{tabular}{|c|c|c|}
\hline & & atau hasil baru \\
\hline 7. & Mandiri & $\begin{array}{l}\text { Tidak bergantung } \\
\text { pada orang lain }\end{array}$ \\
\hline 8. & Demokratis & $\begin{array}{l}\text { Sadar akan kesetaraan } \\
\text { hak dan kewajiban }\end{array}$ \\
\hline 9. & $\begin{array}{l}\text { Rasa Ingin } \\
\text { Tahu }\end{array}$ & $\begin{array}{l}\text { Kesadaran } \\
\text { mengetahui lebih } \\
\text { mendalam dan lebih } \\
\text { luas terhadap apa } \\
\text { yang dilihat, didengar } \\
\text { dan dirasakan. }\end{array}$ \\
\hline 10. & $\begin{array}{l}\text { Semangat } \\
\text { Kebangsaan }\end{array}$ & $\begin{array}{l}\text { Mengutamakan } \\
\text { kepentingan bangsa }\end{array}$ \\
\hline 11. & $\begin{array}{l}\text { Cinta Tanah } \\
\text { Air }\end{array}$ & $\begin{array}{l}\text { Kesetiaan dan } \\
\text { penghargaan tinggi } \\
\text { terhadap bangsa }\end{array}$ \\
\hline 12. & $\begin{array}{l}\text { Menghargai } \\
\text { Prestasi }\end{array}$ & $\begin{array}{lr}\text { Menghasilkan } & \text { hal } \\
\text { berguna } & \text { dan } \\
\text { menghargai } & \\
\text { keberhasilan } & \text { orang } \\
\text { lain } & \\
\end{array}$ \\
\hline 13. & $\begin{array}{l}\text { Bersahabat / } \\
\text { Komunikatif }\end{array}$ & $\begin{array}{l}\text { Senang berinteraksi } \\
\text { dengan orang lain }\end{array}$ \\
\hline 14. & Cinta Damai & $\begin{array}{l}\text { Menghindari } \\
\text { kebencian dan } \\
\text { permusuhan }\end{array}$ \\
\hline 15. & $\begin{array}{l}\text { Gemar } \\
\text { Membaca }\end{array}$ & $\begin{array}{l}\text { Sadar menyempatkan } \\
\text { waktu untuk } \\
\text { membaca }\end{array}$ \\
\hline 16. & $\begin{array}{l}\text { Peduli } \\
\text { Lingkungan }\end{array}$ & $\begin{array}{l}\text { Upaya mencegah } \\
\text { kerusakan pada } \\
\text { lingkungan dan } \\
\text { mengupayakan } \\
\text { pelestarian } \\
\text { lingkungan }\end{array}$ \\
\hline 17. & Peduli Sosial & $\begin{array}{l}\text { Kecenderungan } \\
\text { memberi bantuan dan } \\
\text { meringankan beban }\end{array}$ \\
\hline 18. & $\begin{array}{l}\text { Tanggung } \\
\text { Jawab }\end{array}$ & $\begin{array}{l}\text { Mendahulukan } \\
\text { kewajiban dan tugas } \\
\text { dalam berbagai hal }\end{array}$ \\
\hline
\end{tabular}

Sikap sosial atau perilaku sosial adalah aktivitas fisik dan psikis seseorang terhadap orang lain atau sebaliknya dalam rangka memenuhi diri atau orang lain yang sesuai dengan tuntutan sosial (Hurlock dan Elizabeth, 1995: 262). Tradisi Sambatan yang dilaksanakan di Desa Dermolo secara tidak langsung memberikan pengaruh yang besar bagi kehidupan masyarakat, tidak terkecuali bagi anak-anak Desa Dermolo yang melakukan proses apresiasi terhadap Tradisi Sambatan. Dari kegiatan apresiasi tersebutlah, terbentuk sikap atau perilaku sosial yang mempengaruhi interaksi satu dengan yang lainnya. Nilai-nilai kebersamaan, gotong royong, toleransi, peduli sosial dan peduli lingkungan menjadi hal yang dominan dalam perilaku sosial anak-anak di Desa Dermolo baik yang terlihat dilingkungan keluarga, dilingkungan sekolah maupun dilingkungan masyarakat, terlebih bagi anakanak yang sering melakukan proses apresiasi terlebih yang terlibat langsung dengan kegiatan sambatan dalam kehidupan sehari-hari.

Berdasarkan data yang didapat dari masyarakat yang terlibat dengan Tradisi Sambatan, tokoh masyarakat terutama yang memiliki anak yang masih kecil memang terdapat perbedaan sikap sosial anak antara yang akrab dengan Tradisi Sambatan dan yang tidak. Hasil tersebut didukung dengan data yang didapatkan dari wawancara mendalam dengan praktisi pendidikan di SDN 3 Dermolo dan para siswa itu sendiri sekaligus diperkuat dengan hasil observasi terhadap sikap sosial siswa di lingkungan sekolah. Wujud apresiasi anak-anak terhadap Tradisi Sambatan dapat terlihat dari sikap sosial atau interaksi sosial di berbagai lingkungan. Berdasarkan hasil penelitian, anakanak Desa Dermolo yang dekat dan melakukan proses apresiasi terhadap Tradisi Sambatan memiliki sikap sosial yang sejalan dengan nilainilai karakter yang terkandung didalamnya. Kepekaan sosial anak terhadap lingkungan sekitar atau orang sekitar menjadi hal yang sangat mudah untuk dilihat.

Sikap dan perilaku anak-anak Desa Dermolo dalam kehidupan sehari-hari, baik di rumah, di lingkungan sekolah hingga lingkungan masayarakat menjadi hal yang bisa dilihat dan dirasakan manfaatnya. Sikap sosial yang mencerminkan toleransi, peduli sosial dan peduli lingkungan menjadi hasil dari apresiasi anak-anak terhadap Tradisi Sambatan yang ada di Desa Dermolo. 
Wujud apresiasi anak terhadap Tadisi Sambatan Desa Dermolo:

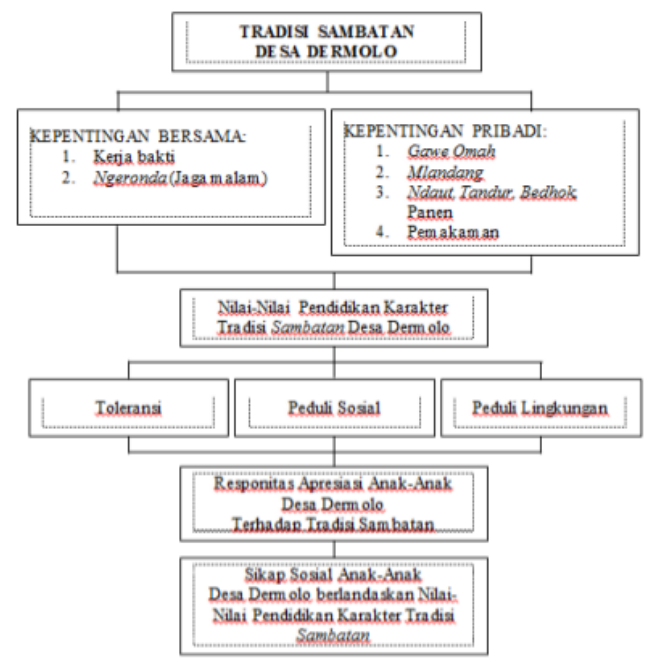

\section{SIMPULAN}

Berdasarkan hasil pemaparan dan analisis data diatas, maka dapat dinyatakan bahwa Tradisi Sambatan yang ada di Desa Dermolo terbagi menjadi dua bentuk sesuai dengan kepentingan, yaitu kepentingan bersama (masyarakat) dan kepentingan pribadi (keluarga). Nilai-nilai pendidikan karakter dalam pembentukan sikap sosial yang ada pada Tradisi Sambatan di Desa Dermolo memberikan pengaruh yang besar bagi kehidupan masayarakat terutama dalam interaksi sosialnya. Tradisi Sambatan yang pada umumnya dilakukan oleh orang dewasa telah mendorong adanya apresiasi dari generasi penerus yaitu anak-anak Desa Dermolo. Sikap sosial anak-anak sebagai respon terhadap Tradisi Sambatan pun bergantung pada proses apresiasi berupa pengamatan, penilaian hingga pemberian respon atau tindakan.

Berawal dari proses apresiasi tersebutlah dapat diketahui keterkaitan antara Tradisi Sambatan dengan sikap sosial anak-anak dalam kehidupan sehari hari. Apresiasi anak-anak Desa Dermolo terhadap Tradisi Sambatan menentukan perkembangan sikap sosial anak dan interaksi sosialnya dalam kehidupan sehari-hari. Keberadaan Tradisi Sambatan membawa pengaruh yang baik bagi kehidupan masyarakat desa secara luas dan mendorong adanya apresiasi dari generasi penerus yaitu anak-anak Desa Dermolo. Nilai-nilai karekter yang terkandung dalam Tradisi Sambatan berpengaruh dalam sikap sosial anak-anak yang melakukan proses apresiasi tersebut, nilai-nilai karakter yang paling menonjol dalam sikap sosial anak-anak Desa Dermolo adalah toleransi, peduli sosial dan peduli lingkungan sesuai dengan bentuk-bentuk Tradisi Sambatan yang ada di Desa Dermolo.

\section{DAFTAR PUSTAKA}

Desmond, K.K. 2011. Ideas About Art. Garsington Road, U. K: Wiley Blackwell.

Gunarto. 2004. Konsep Kurikulum di Indonesia. Rosda Karya: Bandung

Hurlock, Elizabeth. 2003. Psikologi Perkembangan Suatu Pendekatan Sepanjang Rentang Kehidupan. Jakarta: Erlangga.

Jazuli. 2008. Paradigma Kontekstual Pendidikan Seni. Semarang: Unesa University Press.

Listyarti, Retno. 2012. Pendidikan Karakter dalam Metode Aktif, Inovatif dan Kreatif. Jakarta: Penerbit Erlangga.

Kemendiknas. 2011. Panduan Pelaksanaan Pendidikan Karakter. Badan Penelitian dan Pengembangan Pusat Kurikulum dan Perbukuan. Jakarta.

Kus, E. Eddy Sartono. 2018. Pendidikan Nilai Kepedulian Sosial melalui Budaya Sekolah (Study Fenomenologi di SD Tumbuh 1 Yogjakarta). Jurnal Didaktika: Vol. 1 No. 2, 43-50.

Miles, M.B. \& Huberman, A.M. (1992). Analisis data kualitatif (diterjemahkan oleh Tjetjep Rohendi Rohidi). Jakarta. UI Press.

Moleong, Lexy. 2010. Metode Penelitian Kualitatif. Jakarta: UI Press.

Nur, Darmawan. 2009. Peran Pemuda sebagai Penerus Tradisi Sambatan dalam Rangka Pembentukan Karakter Gotong Royong. Vol. 25 No. 1, 57-76.

Rondhi, Moh. 2002. "Tinjauan Seni Rupa 1" Buku Ajar. Semarang: Jurusan Seni Rupa Fakultas Bahasa dan Seni Universitas Negeri Semarang.

Sulhan, Muhammad. 2018. Pendidikan Karakter Berbasis Budaya dalam Menghadapi 
81 First Author, Second Author, \& Third Author (Last Name)

Tantangan Global. Jurnal Visipena: Vol. 9 No. 1, 159-172. 
2I First Author, Second Author, \& Third Author (Last Name)

This page is intentionally left blank 


\section{PERKEMBANGAN SIKAP SOSIAL ANAK MELALUI PROSES APRESIASI TERHADAP TRADISI SAMBATAN DI DESA DERMOLO, JEPARA}

ORIGINALITY REPORT

0

SIMILARITY INDEX
$0 \%$

INTERNET SOURCES
$0 \%$

PUBLICATIONS
$0 \%$

STUDENT PAPERS

PRIMARY SOURCES

Exclude quotes

On

Exclude bibliography
Exclude matches

$<3 \%$ 


\section{PERKEMBANGAN SIKAP SOSIAL ANAK MELALUI PROSES APRESIASI TERHADAP TRADISI SAMBATAN DI DESA DERMOLO, JEPARA}

GRADEMARK REPORT

FINAL GRADE

10

PAGE 1

PAGE 2

PAGE 3

PAGE 4

PAGE 5

PAGE 6

PAGE 7

PAGE 8

PAGE 9
GENERAL COMMENTS

Instructor 